\title{
Invest In India-The Foreign Direct Investment Scenario
}

\author{
Kamaladevi B \\ Dravidian University, Kuppam, Andhra Pradesh, India \\ kamaladevimba@gmail.com
}

\begin{abstract}
Invest in India is an initiative to market India as an investment destination all over the globe, to provide a networking platform to the Indian businesses at a global level and to provide information to the international investors about investment opportunities in India. It is the policy of the Government of India to attract and promote productive Foreign Direct Investment (FDI) from non-residents in activities which significantly contribute to industrialization and socio-economic development. FDI supplements the domestic capital and technology. This paper firstly speaks about the FDI culture in India, secondly, reviews economic reforms in India and global response to India's reforms, the next level discusses the policy issues that would address India's relative lack of success in attracting FDI and the 'Expanding Opportunities for Global Retailers' with reference to the retail sector. The last part reveals the key recommendations towards attracting Diaspora FDI. Based on the objective analysis, the key recommendations towards attracting FDI are revealed like allow $100 \%$ FDI in retail and Small \& Medium Enterprises (SME), develop a strategic vision for FDI with focus on latest technology, reduce the transaction costs \& improve the infrastructure, international and domestic entrepreneurship, decentralize the administration process, reduce overly bureaucratic FDI facilities, private public partnership with private sector taking the lead, Indian professionals placed in key decision making positions, creative joint ventures and partnership to tap entrepreneurship and fix the policies to convert remittances into investment \& create venture capital.
\end{abstract}

Key Words: FDI, FDI culture, Economic reforms, Global investors, FDI requirements

\section{Introduction}

'FDI' means investment by non-resident entity/person resident outside India in the capital of the Indian company under Schedule 1 of FEM (Transfer or Issue of Security by a Person Resident outside India) Regulations 2000 (Government of India, 2010). FDI flows will remain disappointing through 2011, according to the 2010 A.T. Kearney Foreign Direct Investment Confidence Index, a regular assessment of senior executive sentiment at the world's largest companies. The Index also found executives are wary of making investments in the current economic climate and revealed that they expect the economic turnaround to happen not earlier than 2011. Half of the companies surveyed also report that they are postponing investments as a result of market uncertainty and difficulties in obtaining credit.

China remains the top-ranked destination by foreign investors, a title it has held since 2002. The United States retakes second place from India, which had surpassed it in 2005. India, Brazil and Germany complete the top five favored investment destinations. Overall, developed economies rose in the Index as investors looked for safety. The most striking exception is the United Kingdom, whose reliance on financial services left it exposed in the current crisis. At the same time, the placement of China, India and Brazil in the top five shows a strong vote of confidence for the strength of these economies. Investors also expressed the most optimism about the future outlook for China, India and Brazil.

The volume of FDI in India is relatively low comparing to China. This relatively low volume of FDI, especially in comparison with China, has attracted widespread comment and sweeping policy recommendations for increasing the volume of FDI in the country. If China, with its newfound faith in capitalism, can embrace and attract substantial volumes of FDI, why can't India, which is blessed with western institutions and capitalist organizations? This impassioned advocacy of increased flows of FDI into India is based on the well worn arguments that FDI is a rich source of technology and know how and capital to boot, it can invigorate the labor intensive export oriented industries of India, promote technological change in the science based industries and put India on a growth path on par with China. This exuberance for FDI is an article of faith, India is asked to accept it as such, it is not based on an analytical review of India's needs and requirements and it's potential for attracting large rows of FDI. The case for attracting large volumes of FDI into India requires an analysis of FDI culture, economic reforms \& 
policy issues in the Indian context. This is the purpose of this paper which is based on the vast literature on FDI in general and FDI in India in particular.

\section{FDI Confidence Index}

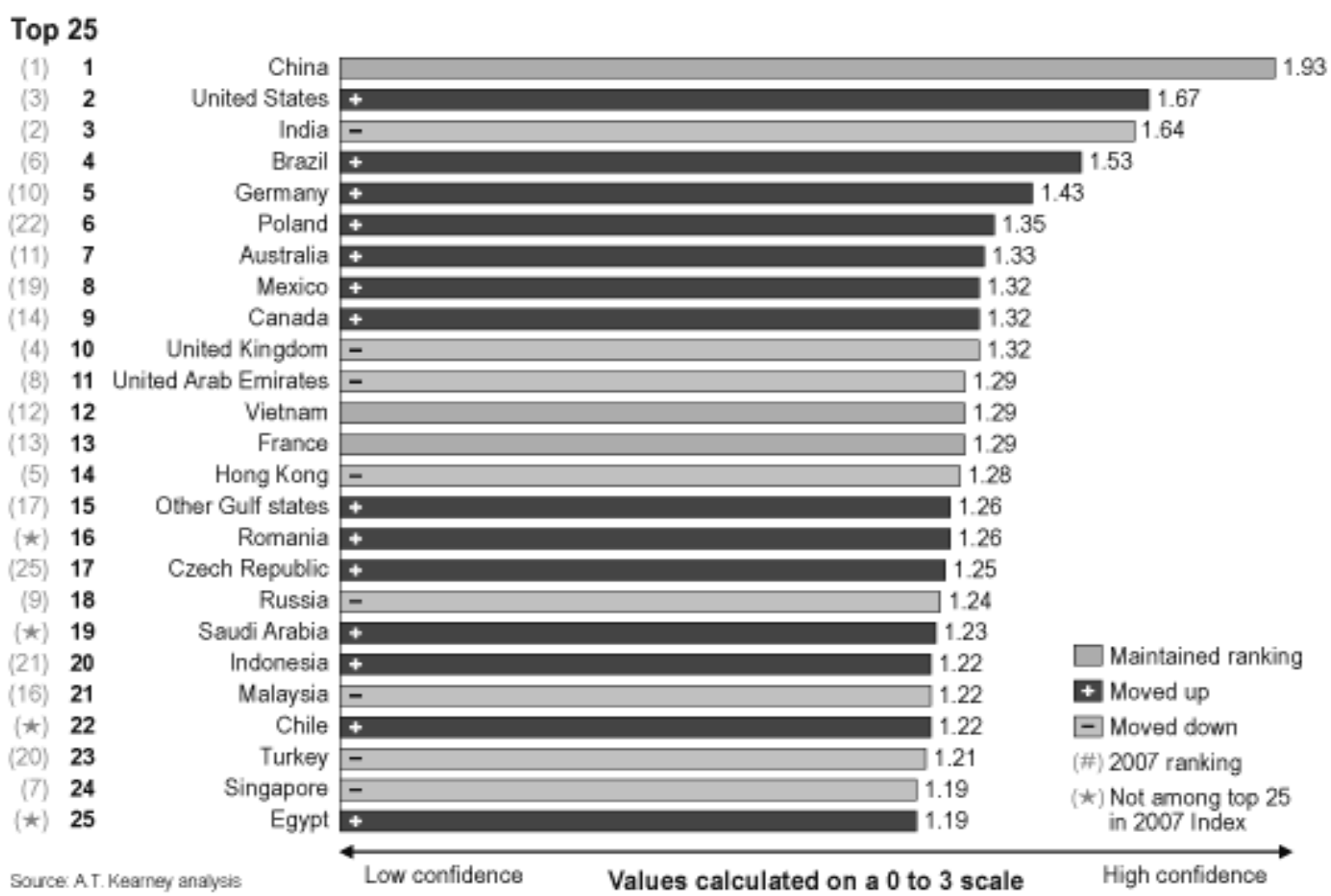

Chart 1: 2010 FDI Confidence Index

Source: A T Kearney analysis 2010 - Foreign Direct Investment Confidence Index

The main objectives of this research paper have five dimensions:

1. Understand the FDI culture in India

2. Review the economic reforms in India and global response to India's reforms

3. Discussion on the policy issues that would address India's relative lack of success in attracting FDI

4. Reveals the 'Expanding Opportunities for Global Retailers' with reference to the retail sector

5. Key Recommendations towards Attracting Diaspora FDI

\section{Review of Literature}

Is India capable of attracting much larger volumes of FDI than it does at present? Should India throw all doors wide open to FDI as advocated by the Harvard economists? Is China's experience a role model for India? The literature on FDI has some light on these issues. Why do firms go abroad? Why do they choose to invest in specific locations? The origins of the theoretical literature on determinants of FDI are to be found in Hymer's (1976) doctoral dissertation. His thesis briefly put is that firms go abroad to exploit the rents inherent in the monopoly over advantages they possess and FDI is their preferred mode of operations. The advantages firms possess include patented technology, team specific managerial skills, marketing skills and brand names. All other methods of exploiting these advantages in external markets such as licensing agreements and exports are inferior to FDI because the market for knowledge or advantages possessed by firms tends to be imperfect. In other words, they do not permit firms to exercise control over operations essential for retaining and fully exploiting the advantages they own.

Hymer's insights form the basis for other explanations such as the transactions costs and internalization theories (Buckley and Casson, 1991), most of which in essence argue that firms internalize operations, forge backward and forward linkages in order to by-pass the market with all its imperfections. Dunning 
(1973) neatly synthesizes these and other explanations in the well-known eclectic paradigm or the OLI explanation of FDI. For a firm to successfully invest abroad it must possess advantages which no other firm possess (O), the country it waits to invest in should offer location advantages (L), and it must be capable of internalizing operations (I). Internalization is synonymous with the ability of firms to exercise control over operations. And such control is essential for the exploitation of the advantages which firms possess and the location advantages which host countries offer.

It is the location advantages emphasized by Dunning, which forms the core of much of the discussion on the determinants of FDI in developing countries. The two other attributes necessary for FDI are taken as given from the perspective of developing countries. Dunning (1973) set the ball rolling on econometric studies with a statistical analysis of survey evidence on the determinants of FDI. His study identified three main determinants of FDI in a particular location; market forces (including market size and growth, as determined by the national income of the recipient country), cost factors (such as labour cost and availability and the domestic inflation situation) and the investment climate (as determined by such considerations as the extent of foreign indebtedness and the state of the balance of payments). Dunning's $(1973,1993)$ analysis proved influential and were pursued further by others (Agarwal, 1980, Agarwal, 2000, Root and Ahmed, 1979, Levis, 1979, Balasubramanyam and Salisu, 1991, Balasubramanyam, Salisu and Sapsford, 1999). Although the empirical literature continues to grow unabated both in size and econometric sophistication, its overall message can be briefly summarised in the form of the following propositions.

1. Host countries with sizeable domestic markets, measured by GDP per capita and sustained growth of these markets, measured by growth rates of GDP, attract relatively large volumes of FDI.

2. Resource endowments of host countries including natural resources and human resources are a factor of importance in the investment decision process of foreign firms.

3. Infrastructure facilities including transportation and communication networks are an important determinant of FDI.

4. Macroeconomic stability, signified by stable exchange rates and low rates of inflation is a significant factor in attracting foreign investors. Political stability in the host countries is an important factor in the investment decision process of foreign firms.

5. A stable and transparent policy framework towards FDI is attractive to potential investors.

6. Foreign firms place a premium on a distortion free economic and business environment. An allied proposition here is that a distortion free foreign trade regime, which is neutral in terms of the incentives it provides for import substituting (IS) and export industries (EP), attracts relatively large volumes of FDI than either an IS or an EP regime.

7. Fiscal and monetary incentives in the form of tax concessions do play a role in attracting FDI, but these are of little significance in the absence of a stable economic environment.

How does India fare on these attributes? It does possess a large domestic market, it has achieved growth rates of around 5 to 6 percent per annum in recent years, its overall record on macroeconomic stability, save for the crisis years of the late eighties, is superior to that of most other developing countries. And judged by the criterion of the stability of policies it has displayed a relatively high degree of political stability. It is, however, India's trade and FDI regimes which are seen as major impediments to increased inflows of FDI. The product and factor market distortions generated by the inward looking import substitution industrial policies India pursued until recently have been widely discussed. So it's too complex and cumbersome FDI regime in place until the nineties.

\section{Research Methodology}

A descriptive research design suits to achieve the five dimension objectives. Data are collected through secondary sources like research reports and websites. Secondary data, which is published by RBI, is referred here. Primary data cannot be taken because it is a country wise report analysis. The literature survey is done for the past six months about the FDI Scenario in India. Based on the analysis, the research paper is written. The limitation of this research paper is, there are many aspects which determine the FDI scenario in India, but very few aspects are discussed here. This limitation will be overcome in the future research. 


\section{FDI Culture in India}

Many economists in the country have now realized the advantages of FDI to India. While the achievements of the Indian government are to be lauded, a willingness to attract FDI has resulted in what could be termed an "FDI Industry". While researching the economic reforms on FDI, it was discovered that there exists a plethora of boards, committees, and agencies that have been constituted to ease the flow of FDI. A call to one agency about their mandate and scope usually results in the quintessential response to call someone else. Reports from FICCI and the Planning Commission place investor confidence and satisfaction at an all time high; citizens too deserve to be clued in on the government bodies are doing. According to the current policy FDI can come into India in two ways. Firstly FDI up to $100 \%$ is allowed under the automatic route in all activities/sectors except a small list that require approval of the Government. FDI in sectors/activities under automatic route does not require any prior approval either by the Government or RBI. The investors are required to notify the Regional office concerned of RBI within 30 days of receipt of inward remittances and file the required documents with that office within 30 days of issue of shares to foreign investors. All proposals for foreign investment requiring Government approval are considered by the Foreign Investment Promotion Board (FIPB). The FIPB also grants composite approvals involving foreign investment/foreign technical collaboration.

The face of FDI usually resides with pamphlets and amalgamation of facts and figures that are circulated through many conferences. From these it can be deciphered that officially FDI policy is reviewed on an ongoing basis and measures for its further liberalization are taken. The change in sectoral policy/ sectoral equity cap is notified from time to time through Press Notes by the Secretariat for Industrial Assistance (SIA) in the Department of Industrial Policy \& Promotion. Policy announcement by SIA are subsequently notified by Reserve Bank of India (RBI) under Foreign Exchange Management Act (FEMA). Thus while clear procedures have been established for FDI, government needs to seriously evaluate how much resources and money is being poured to what is becoming the FDI industry. The fluidity of bodies has resulted in the monetary value of FDI feeding a makeshift industry that deals with dealing with the concept and procedures of FDI.

\section{Doing Business in India - World Bank}

The World Bank conducts an annual study on "Doing Business in India" (World Bank 2007). The next report available in Doing Business 2008 and in this report, India is ranked a rather inglorious 120 out of 178 economies. The report is based on a "series of annual reports investigating the regulations that enhance business activity and those that constrain it. Doing Business presents quantitative indicators on business regulations and the protection of property rights that can be compared across 178 economies from Afghanistan to Zimbabwe and over time. The report considers 10 indicators and they are fairly selfexplanatory. These indicators are; starting a business, dealing with licenses, employing workers, registering property, getting credit, protecting investors, paying taxes, trading across borders, enforcing contracts and closing a business.

Table 1: Doing Business in India

\begin{tabular}{llr}
\hline & & Rank \\
\hline & Easy of Doing Business & 120 \\
1 & Starting a Business & 111 \\
2 & Dealing with Licenses & 134 \\
3 & Employing Workers & 85 \\
4 & Registering Property & 112 \\
5 & Getting Credit & 36 \\
6 & Protecting Investors & 33 \\
7 & Paying Taxes & 165 \\
8 & Trading Across Borders & 79 \\
9 & Enforcing Contracts & 177 \\
10 & Closing a Business & 137 \\
\hline
\end{tabular}

Source: Doing Business: World Bank

India fairs "decently" in only two areas, viz. getting credit and protecting investors' categories. Perhaps the truly embarrassing rank is for the "enforcing contracts" category in which India is ranked a dismal 
177 out of 178 countries. According to the report, it takes 1420 days to enforce a contract and the cost to enforce that contract is almost two-fifths of the claim. This is a key concern for businesses.

Table 2: FDI Equity Inflows (Month-Wise) During the Calendar Year 2010

\begin{tabular}{|c|c|c|c|}
\hline \multirow{2}{*}{\multicolumn{2}{|c|}{$\begin{array}{c}\text { Calendar Year } 2010 \\
\text { (Jan.-Dec.) }\end{array}$}} & \multicolumn{2}{|c|}{ Amount of FDI inflows } \\
\hline & & (In Crores) & (In US\$ mn) \\
\hline 1. & January 2010 & 9,386 & 2,042 \\
\hline 2. & February 2010 & 7,955 & 1,717 \\
\hline 3 & March 2010 & 5,497 & 1,209 \\
\hline 4. & April 2010 & 9,697 & 2,179 \\
\hline 5. & May 2010 & 10,135 & 2,213 \\
\hline 6. & June 2010 & 6,429 & 1,380 \\
\hline 7. & July 2010 & 8,359 & 1,785 \\
\hline 8. & August 2010 & 6,196 & 1,330 \\
\hline 9. & September 2010 & 9,754 & 2,118 \\
\hline 10 & October 2010 & 6,185 & 1,392 \\
\hline 11. & November 2010 & 7,328 & 1,628 \\
\hline Year 201( & November 2010) & 86,921 & 18,993 \\
\hline Year 200 & November 2009) & 123,795 & 25,504 \\
\hline \%age gro & er last year & $(-) 30 \%$ & $(-) 26 \%$ \\
\hline
\end{tabular}

Table 2 clearly shows the month wise FDI Equity inflows during the calendar year 2010. The \% of FDI inflows come down by $30 \%$ comparing to 2009 .

Table 3: Share of Top Investing Countries FDI Equity Inflows (Financial years) Amount`in Crores (US\$ in million)

\begin{tabular}{|c|c|c|c|c|c|c|}
\hline Ranks & Country & $\frac{\text { 2008-09 }}{\text { (Apr-Mar) }}$ & $\frac{\text { 2009-10 }}{\text { (Apr-Mar) }}$ & $\frac{\text { 2010-11 }}{\text { (Apr-Nov) }}$ & $\frac{\text { Cumulative }}{\underline{\text { Inflows }}}$ & $\begin{array}{l}\text { \%age to total } \\
\text { Inflows }\end{array}$ \\
\hline 1. & Mauritius & $\begin{array}{r}50,899 \\
(11,229)\end{array}$ & $\begin{array}{r}49,633 \\
(10,376)\end{array}$ & $\begin{array}{r}23,576 \\
(5,158)\end{array}$ & $\begin{array}{r}234,482 \\
(52,398)\end{array}$ & $42 \%$ \\
\hline 2. & Singapore & $\begin{array}{r}15,727 \\
(3,454)\end{array}$ & $\begin{array}{r}11,295 \\
(2,379)\end{array}$ & $\begin{array}{r}6,198 \\
(1,367)\end{array}$ & $\begin{array}{r}51,344 \\
(11,557)\end{array}$ & $9 \%$ \\
\hline 3. & U.S.A. & $\begin{array}{r}8,002 \\
(1,802)\end{array}$ & $\begin{array}{r}9,230 \\
(1,943)\end{array}$ & $\begin{array}{l}4,247 \\
(926)\end{array}$ & $\begin{array}{l}41,436 \\
(9,204)\end{array}$ & $7 \%$ \\
\hline 4. & U.K. & $\begin{array}{l}3,840 \\
(864)\end{array}$ & $\begin{array}{l}3,094 \\
(657)\end{array}$ & $\begin{array}{l}1,765 \\
(385)\end{array}$ & $\begin{array}{r}27,764 \\
(6,269)\end{array}$ & $5 \%$ \\
\hline 5. & Netherland & $\begin{array}{l}3,922 \\
(883)\end{array}$ & $\begin{array}{l}4,283 \\
(899)\end{array}$ & $\begin{array}{l}3,643 \\
(802)\end{array}$ & $\begin{array}{r}23,769 \\
(5,289)\end{array}$ & $4 \%$ \\
\hline 6. & Japan & $\begin{array}{l}1,889 \\
(405)\end{array}$ & $\begin{array}{r}5,670 \\
(1,183)\end{array}$ & $\begin{array}{l}4,141 \\
(917)\end{array}$ & $\begin{array}{r}21,036 \\
(4,631)\end{array}$ & $4 \%$ \\
\hline 7. & Cyprus & $\begin{array}{r}5,983 \\
(1,287)\end{array}$ & $\begin{array}{r}7,728 \\
(1,627)\end{array}$ & $\begin{array}{l}2,746 \\
(598)\end{array}$ & $\begin{array}{r}20,523 \\
(4,498)\end{array}$ & $4 \%$ \\
\hline 8. & Germany & $\begin{array}{l}2,750 \\
(629)\end{array}$ & $\begin{array}{l}2,980 \\
(626)\end{array}$ & $\begin{array}{r}473 \\
(104)\end{array}$ & $\begin{array}{r}12,941 \\
(2,903)\end{array}$ & $2 \%$ \\
\hline 9 & France & $\begin{array}{l}2,098 \\
(467)\end{array}$ & $\begin{array}{l}1,437 \\
(303)\end{array}$ & $\begin{array}{l}1,569 \\
(340)\end{array}$ & $\begin{array}{r}8,488 \\
(1,870)\end{array}$ & $2 \%$ \\
\hline 10. & U.A.E. & $\begin{array}{l}1,133 \\
(257)\end{array}$ & $\begin{array}{l}3,017 \\
(629)\end{array}$ & $\begin{array}{l}1,289 \\
(278)\end{array}$ & $\begin{array}{r}8,312 \\
(1,828)\end{array}$ & $1 \%$ \\
\hline \multicolumn{2}{|c|}{ Total FDI Inflows } & $\begin{array}{l}123,025 \\
(27,331)\end{array}$ & $\begin{array}{r}123,120 \\
(25,834)\end{array}$ & $\begin{array}{r}64,083 \\
(14,025)\end{array}$ & $\begin{array}{r}556,819 \\
(124,436)\end{array}$ & - \\
\hline
\end{tabular}

Table 3 speaks about the share of top investing countries FDI equity inflows, in which Mauritius hold the highest of $42 \%$. 
Table 4: Sectors Attracting Highest FDI Equity Inflows (Amount in Crores US\$ in million)

\begin{tabular}{|c|c|c|c|c|c|c|}
\hline Ranks & Sector & $\frac{2008-09}{\text { (Apr-Mar) }}$ & $\frac{\text { 2009-10 }}{\text { (Apr-Mar) }}$ & $\frac{\text { 2010-11 }}{\text { (Apr-Nov) }}$ & $\frac{\text { Cumulative }}{\underline{\text { Inflows }}}$ & $\begin{array}{l}\text { \% age } \\
\text { to total } \\
\text { Inflows }\end{array}$ \\
\hline 1. & $\begin{array}{l}\text { Services Sector } \\
\text { (financial \& non-financial) }\end{array}$ & $\begin{array}{r}28,516 \\
(6,138)\end{array}$ & $\begin{array}{r}20,776 \\
(4,353)\end{array}$ & $\begin{array}{l}11,885 \\
(2,596)\end{array}$ & $\begin{array}{l}117,114 \\
(26,197)\end{array}$ & $21 \%$ \\
\hline 2. & $\begin{array}{l}\text { Computer Software \& } \\
\text { Hardware }\end{array}$ & $\begin{array}{r}7,329 \\
(1,677)\end{array}$ & $\begin{array}{l}4,351 \\
(919)\end{array}$ & $\begin{array}{l}2,617 \\
(574)\end{array}$ & $\begin{array}{r}46,464 \\
(10,446)\end{array}$ & $8 \%$ \\
\hline 3. & $\begin{array}{l}\text { Telecommunications } \\
\text { (radio paging, cellular } \\
\text { mobile, basic telephone } \\
\text { services) }\end{array}$ & $\begin{array}{r}11,727 \\
(2,558)\end{array}$ & $\begin{array}{r}12,338 \\
(2,554)\end{array}$ & $\begin{array}{r}4,962 \\
(1,093)\end{array}$ & $\begin{array}{r}45,668 \\
(10,023)\end{array}$ & $8 \%$ \\
\hline 4. & Housing \& Real Estate & $\begin{array}{r}12,621 \\
(2,801)\end{array}$ & $\begin{array}{r}13,586 \\
(2,844)\end{array}$ & $\begin{array}{l}4,569 \\
(999)\end{array}$ & $\begin{array}{r}41,938 \\
(9,356)\end{array}$ & $8 \%$ \\
\hline 5. & \begin{tabular}{lll}
\multicolumn{2}{l}{ Construction Activities } & \\
(including & roads & \& \\
highways) & &
\end{tabular} & $\begin{array}{r}8,792 \\
(2,028)\end{array}$ & $\begin{array}{r}13,516 \\
(2,862)\end{array}$ & $\begin{array}{l}3,762 \\
(834)\end{array}$ & $\begin{array}{r}39,455 \\
(8,887)\end{array}$ & $7 \%$ \\
\hline 6. & Power & $\begin{array}{l}4,382 \\
(985)\end{array}$ & $\begin{array}{r}6,908 \\
(1,437)\end{array}$ & $\begin{array}{l}4,491 \\
(984)\end{array}$ & $\begin{array}{r}25,411 \\
(5,611)\end{array}$ & $5 \%$ \\
\hline 7. & Automobile Industry & $\begin{array}{r}5,212 \\
(1,152)\end{array}$ & $\begin{array}{r}5,754 \\
(1,208)\end{array}$ & $\begin{array}{l}2,399 \\
(533)\end{array}$ & $\begin{array}{r}23,221 \\
(5,129)\end{array}$ & $4 \%$ \\
\hline 8. & Metallurgical Industries & $\begin{array}{l}4,157 \\
(961)\end{array}$ & $\begin{array}{l}1,935 \\
(407)\end{array}$ & $\begin{array}{l}4,402 \\
(960)\end{array}$ & $\begin{array}{r}17,842 \\
(4,090)\end{array}$ & $3 \%$ \\
\hline 9. & Petroleum \& Natural Gas & $\begin{array}{l}1,931 \\
(412)\end{array}$ & $\begin{array}{l}1,328 \\
(272)\end{array}$ & $\begin{array}{l}2,421 \\
(529)\end{array}$ & $\begin{array}{r}13,925 \\
(3,195)\end{array}$ & $3 \%$ \\
\hline 10. & $\begin{array}{l}\text { Chemicals } \\
\text { (other than fertilizers) }\end{array}$ & $\begin{array}{l}3,427 \\
(749)\end{array}$ & $\begin{array}{l}1,707 \\
(362) \\
\end{array}$ & $\begin{array}{l}1,238 \\
(271)\end{array}$ & $\begin{array}{r}12,513 \\
(2,767) \\
\end{array}$ & $2 \%$ \\
\hline
\end{tabular}

Table 4 lists the sectors attracting highest FDI equity inflows, in which service sector holds the highest of $21 \%$ and the list goes on.

\section{Economic Reforms in India}

Major economic reforms in India have been associated with crises. For example, after nearly two decades of industry-oriented planning, India accorded due importance to the agricultural sector in the late 1960s, in response to massive food shortages. The consequence of the policy shift was the Green Revolution in the early 1970s. The balance of payments crisis of the early 1980s, together with the stagnation that had become known as the "Hindu" rate of growth, precipitated the "new" economic policy of 1984-85, in which lay the genesis for the economic reforms of the 1990s. The reforms process in the 1980s was aimed mostly at opening up the economy to import competition, and at streamlining the process of tax administration. The much discussed economic reforms of the 1990s, the first sustained effort at restructuring the economy, came in response to another balance of payments crisis in 1991, when India was left with two weeks' import cover. The government reacted by ushering in sweeping macroeconomic and structural changes. Direct tax rates were reduced for both individuals and corporate entities, with the expectation that reduced tax rates would lead to greater compliance. Tariff rates too were reduced, and the peak tariff rate came down from 350 percent in 1990-91 to 35 percent in 2000-01. The structure of the other indirect taxes was rationalized, and a process was put in place to enable the introduction of value added tax in the foreseeable future.

Licensing was eliminated, and firms in all but a few sectors were allowed to start operations without government approval. The impact of de-licensing was most evident in sectors like steel, automobiles, FMCG and consumer electronics which witnessed a surge in entry of new firms. Over time, capital account restrictions were eased to allow Indian companies to raise capital abroad, by way of Eurobonds and GDR/ADRs, and acquire firms in other countries. The domestic capital market was restructured with the Securities and Exchange Commission and the National Stock Exchange as the driving forces, and interest rates were liberalized. In brief, market forces were unleashed both in the product and, by and large, in the 
factor markets, and firms were given much more freedom to realize gains associated with allocation efficiency.

The government also made is easier for MNCs to invest in India. Today, India welcomes foreign investment in virtually all sectors except defence, railway transport and atomic energy. In sectors like road and port infrastructure, mining of gold and minerals, and pharmaceuticals, MNCs can own up to 100 percent of their Indian affiliates without government approval. In certain other lines of business like generation of power and development of integrated townships, 100 percent foreign ownership is possible with government approval. In activities like exploration for petroleum reserves, development of marketing infrastructure for petroleum products, and exploration and mining of coal, MNCs are allowed majority stake in the affiliate. Usually varying between 51 percent and 74 percent. In most cases, however, their stakes in SOEs are restricted to 26 percent. Finally, in sectors like media and insurance, MNCs are restricted to minority stake, and are expected to obtain government approval prior to initiation of business.

All is not well with the business environment in India, however. Aside from continuing bureaucratization of many processes affecting business, the reforms process in India has three weak links. First, the policy of protecting small firms in some sectors has not completely been eliminated, thereby preventing entry of larger and more solvent firms, with greater economies of scale, to these sectors. This has had an adverse impact on the competitiveness of firms in these sectors. Second, privatization in India has largely been a tame affair; despite some major privatization deals involving companies like the aluminum giant BALCO, the (former) telecom monopoly VSNL and the country's flagship (automobile) product Maruti Suzuki. Successive governments have failed to meet privatization targets and privatization of large and inefficient firms like Indian Airlines and Air India have repeatedly been postponed. Third, the labour code remains largely unchanged, and closure of bankrupt firms remains a difficult and tedious process.

\section{Global Response to India's Reforms}

How has the rest of the world reacted to the width and depth of the Indian reforms? As measured by the quantum of FDI inflow, global response has been, by and large, positive. The annual flow of FDI rose from a paltry USD 0.1 billion in 1991 to USD 4.28 billion in 2001. FDI in 2001 accounted for 1 percent of GDP and 4.3 percent of domestic investment, the corresponding figures for 1991 being 0.07 and 0.12 respectively. However, the aggregate stock of FDI received by India during the 1990s stands at a low USD 18 billion, less than half of China's annual flow of FDI. From the average policymaker's perspective, more worrisome is the fact that an exponential growth in FDI inflow is not expected in the near future, despite the elimination of a large number of barriers to FDI during the last 10 years (Kathuria, 2000).

In order to better understand the reason behind India's sub-expectations performance, in so far as quantum of FDI is concerned, one has to probe at the sub- national level. Specifically, one has to understand the nature and ex post views of the MNCs investing India. Are they large MNCs, for example, who want to have a small exposure to India by way of a downstream affiliate or are they largely in sectors like financial services where there is a lot of scope for transfer of technology and knowhow but little scope for significant transfer of capital? Are the spillover effects of entry, by way of technology transfer, training of personnel and export growth, significant such that the inflow of relatively small quantum of capital is supplemented by significant intangible gains? Are they entering largely by way of Joint Ventures where the investment is split between MNCs and local firms, thereby reducing the MNCs contribution to capital? Given the possible relationship between entry mode choice and the aforementioned intangibles, what determines the choice of the entry mode? Are MNCs that are in operation in India meeting their expectation about performance, thereby signaling to others that investment in India is worthwhile?

\section{Discussion on the policy issues that would address India's relative lack of success in attracting FDI}

\section{Dynamics of FDI in India and China}

The strength of the Chinese Diaspora in managing transnational export businesses based on low cost, small scale manufacturing is further strengthened through a very strong network of ethnic Chinese businesses across the world. This network helps the Diaspora entrepreneurial community to reduce the transaction cost of managing trade across borders even without the kind of capital and marketing 
networks of their larger MNC competitors. As Kao points out, 39\% of business relations of Chinese firms in SE Asia were with other Chinese firms. The Indian Diaspora lacks such business networks, which is not surprising, given that a very large proportion of Indian diaspora are not directly engaged in manufacturing, but is either professionals or engaged in services oriented businesses. However, the Indian diaspora has been successful in certain niche export-oriented global trading networks, a good example being the diamond cutting and retailing network managed by Indian entrepreneurs based in South Africa, Surat (in Gujarat), Amsterdam and New York. An interesting point that needs to be made here is that the development of Surat as a global centre of diamond cutting industry and the emergence of a competitive diamond trading community of Indians across the world did not require SEZs or special government policies. It happened because the right conditions, i.e. skilled entrepreneurs, feasible low cost and small scale manufacturing base (Surat) and existence of transnational business connections strengthened by Diaspora links developed over the years. The importance of being a low cost manufacturing base and having extensive international trade ties is very significant.

According to Wei (2005), China's emergence as a low cost manufacturing base and sustained export growth through much of the 1980's and 1990's is an important reason behind its relative success in attracting FDI, not just of the Diaspora variety, but in general. Investors from OECD economies will invest in an economy if they see plausible long-term gains. Such gains will arise out of either domestic opportunities in that economy or its ability to be a competitive base for third country exports. India has lagged far behind China in terms of Trade Facilitation and export sector promotion in manufacturing and agriculture, and it is only in recent times that FDI geared towards third country markets has been coming into India. A good example is the automotive parts industry where India has recently emerged as a very competitive player and FDI into this sector has taken off. Given India's large domestic market opportunities, FDI in several other sectors is bound to take off in the coming years. The important point is that policies and investment facilitation are part of larger set of factors that influence FDI; they cannot substitute hard economic considerations. Unless India reduces the transaction costs in manufacturing and agriculture, undertakes radical reforms in trade facilitation and export promotion to become an international production hub, and addresses key infrastructure issues such as energy and transportation costs, FDI, whether Diaspora or MNC variety, will not reach India.

A good example that supports this argument of FDI dynamics influenced by global market opportunities coupled with Diaspora expertise and networks is the IT and ITES sector in India. India's professional IT and management oriented diaspora realized the cost arbitration offered by off shoring IT and ITES work to India. Given the Diaspora expertise in this sector and the strong linkages amongst the Diaspora community in the Silicon Valley, it did not take long before several startups took place in Bangalore and Hyderabad followed by rest of India. An important point that needs to be made here is that the diaspora had a role as an entrepreneur as well as arbitrators of MNC investment into India in this sector where Indian manager-professionals engaged with MNCs took the lead in bringing significant investment into India. Just like the Chinese diaspora's global networks helped small entrepreneurs to tap the global market successfully, the Indian Diaspora network in IT and ITES helped small Indian start-ups (with seed capital of less 3-4 million USD) succeed globally. The transaction costs of exporting services where relatively low in India compared to manufacturing, it did not have to depend on India's poor quality of roads, logistics shipping infrastructure. Proactive policies in the IT sector initiated in the mid 1980's also helped. Thus, given the right conditions, the Indian diaspora will be second to none in seeking economic opportunities in their countries of origin and contribute to its economic growth.

\section{FDI Requirement}

The requirement for FDI arises out of three basic rationale; first, to meet the gap between required investments to funnel economic growth and national savings, second, to get strategic technology transfer and managerial expertise, and third, to add to the competitive edge for exports given the international linkages arising out of FDI. 


\section{Foreign Direct Investment (FDI)}

\begin{tabular}{|c|c|c|c|c|c|c|c|}
\hline & Equity & & & & FDI flc & into India & \\
\hline 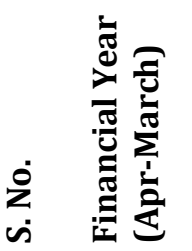 & $\begin{array}{l}\text { RBI's } \\
\text { Automati } \\
\text { c Route/ } \\
\text { Acquisiti } \\
\text { on Route }\end{array}$ & $\begin{array}{l}\text { Equity } \\
\text { capital of } \\
\text { unincorpo } \\
\text { rated } \\
\text { bodies \# }\end{array}$ & 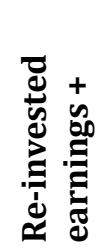 & 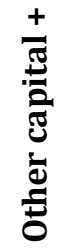 & 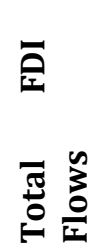 & $\begin{array}{l}\text { \%age } \\
\text { growth } \\
\text { over } \\
\text { previous } \\
\text { year }\end{array}$ & 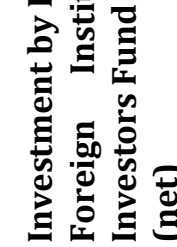 \\
\hline
\end{tabular}

Financial Years 2000-2011

\begin{tabular}{|c|c|c|c|c|c|c|c|c|}
\hline 1 & $2000-01$ & 2,339 & 61 & 1,350 & 279 & 4,029 & - & 1,847 \\
\hline 2 & 2001-02 & 3,904 & 191 & 1,645 & 390 & 6,130 & (+) $52 \%$ & 1,505 \\
\hline 3 & 2002-03 & 2,574 & 190 & 1,833 & 438 & 5,035 & (-) $18 \%$ & 377 \\
\hline 4 & 2003-04 & 2,197 & 1,460 & 1,460 & 633 & 4,322 & (-) $14 \%$ & 10,918 \\
\hline 5 & 2004-05 & 3,250 & 1,904 & 1,904 & 369 & 6,051 & (+) $40 \%$ & 8,686 \\
\hline 6 & 2005-06 & 5,540 & 2,760 & 2,760 & 226 & 8,961 & (+) $48 \%$ & 9,926 \\
\hline 7 & 2006-07 & 15,585 & 5,828 & 5,828 & 517 & 22,826 & (+) $146 \%$ & 3,225 \\
\hline 8 & 2007-08 & 24,573 & 7,679 & 7,679 & 292 & 34,835 & (+) $53 \%$ & 20,328 \\
\hline 9 & 2008-09 & 27,329 & 9,030 & 9,030 & 777 & 37,838 & (+) $09 \%$ & (-) 15,017 \\
\hline 10 & $\begin{array}{l}2009-10 \\
(\mathrm{P}) \\
(+)(++)\end{array}$ & 25,609 & 8,669 & 8,669 & 1,945 & 37,763 & $(-) 0.2 \%$ & 29,048 \\
\hline 11 & $\begin{array}{l}\text { (up to } \\
\text { Novembe } \\
\text { r 2010) }\end{array}$ & 14,025 & 4,237 & 4,237 & 303 & 19,002 & - & 31,007 \\
\hline \multirow{2}{*}{\multicolumn{2}{|c|}{$\begin{array}{l}\text { Cumulative } \\
\text { Total } \\
\text { (from } \\
2000 \quad \text { April } \\
\end{array}$}} & 126,925 & 7,303 & 46,395 & 6,169 & 186,792 & - & 101,850 \\
\hline & & & & & & & & \\
\hline
\end{tabular}

Source:_ RBI’s Bulletin January 2011 dt. 12.01 .2011 (Foreign Investment Inflows)

Table 5 shows FDI inflows as per international best practices in which investments by Foreign Institutional Investors are growing positive in 2010.

\section{Expanding Opportunities for Global Retailers' with reference to the retail sector}

1. Carrefour, the world's second-largest retailer, has opened its first cash-and-carry store in India in New Delhi. Germany-based wholesale company Metro Cash \& Carry (MCC) opened its second wholesale centre at Uppal in Hyderabad, taking to its number to six in the country.

2. Electronic retail chain major, Next Retail India, plans to open 400 showrooms across the country during January-March 2011 increasing the total number of retail stores to 1,000 by the end of the fiscal year 2010-11.

3. Jewellery retail store chain Tanishq plans to open 15 new retail stores in various parts of the country in the 2011-12 fiscal.

4. V Mart Retail Ltd, a medium-sized hypermarket format retail chain, is set to open 40 outlets over the next three years, starting with 13 stores in 2011, in Tier-II and Tier-III cities.

5. Reliance Retail, the wholly owned subsidiary of Mukesh Ambani's Reliance Industries, is set to open 150 stores by the end of March 2011 and double the number of stores across the country in all formats within five years.

6. Future Value Retail, a Future Group venture, will take its hypermarket chain Big Bazaar to smaller cities of Andhra Pradesh, with an investment of around US\$ 1.54 million to US\$ 4.41 million depending on the size and format.

7. RPG-owned Spencer's Retail plans to set up 15-20 new stores in the country in 2011-12. 
8. Spar Hypermarkets, the global food retailing chain of the Dubai-based Landmark Group, expects to start funding its India expansion beyond 2013 out of its local cash flow in the country. So far, the Landmark Group has invested US\$ 51.31 million in setting up five hypermarkets and plans to pump in another US\$51.31 million into the next phase of expansion.

9. Leading watchmaker Titan Industries Limited plans to invest about US\$21.83 million for opening 50 premium watch outlets Helios in next five years to attain a sales target of US\$ 87.31 million.

10. British high street retailer, Marks and Spencer (M\&S) plans to significantly increase its retail presence in India, targeting 50 stores in the next three years.

11. Spain's Inditex, Europe's largest clothing retailer opened the first store of its flagship Zara brand in India in June 2010. It further plans to open a total of five Zara outlets in India.

12. Bharti Retail, owner of Easy Day store-supermarkets and hyper marts-plans to invest about US $\$ 2.5$ billion over the next five years to add about 10 million sq $\mathrm{ft}$ of retail space in the country by then, according to a company spokesperson.

\section{Policy Initiatives}

100 per cent FDI is permitted under the automatic route for trading companies for cash \& carry trading wholesale trading/ wholesale trading. FDI up to 51 per cent under the Government route is allowed in retail trade of Single Brand products, according to the Consolidated FDI Policy document. The Consumer Affairs Ministry has given the green signal to allow 49 per cent FDI in multi-brand retail. It has written a letter to this effect to the Commerce Ministry. "Multi-brand retail should be permitted with a cap of 49 per cent... A significant chunk of investments should be spent on back-end infrastructure, besides logistics and agro-processing," the Consumer Affairs Ministry had said in response to the discussion paper floated by the Department of Industrial Policy and Promotion in June 2010 on allowing 100 per cent FDI in multibrand retail. The Securities and Exchange Board of India (SEBI) has notified the increase in the retail investment limit to US\$ 4,391.19 in initial public offers (IPOs). The new norms will be applicable to issues that have yet not opened for subscription (Government of India 2010).

Thus, major international brands are in the process of expanding their retail presence. For instance, Paul \& Shark now has two stores with Hyderabad and will have few more by next year, Zegna, another Italian brand, known for its formal wear and quality suits, is also expanding and Diesel will have seven stores in the country. Meanwhile, European football clubs, including Manchester United, Chelsea and Liverpool, are increasingly scouting for partnerships in India to sell their merchandise and also set up chain of coffee clubs and theme shops. The stationery retailing market in India is also witnessing steady growth due to the arrival of organised players in the business. It is estimated that the Indian office products industry is in the range of US\$2.22 billion with stationery comprising US\$ 666.89 million-US\$ 889.19 million and growing at 30 per cent per annum. Future Group and Reliance Retail are some of the players who are already tapping into the sector and have launched brands such as Staples and Office Depot.

\section{Research Discussion \& Key Recommendations towards Attracting Diaspora FDI}

\section{Allow 100 \% FDI in retail and Small \& Medium Enterprises (SME)}

FDI in SME's is limited to only $24 \%$, with any foreign investment above $24 \%$ being subject to industrial license with a mandatory export obligation of $50 \%$ of annual production and the manufacturer losing small scale status. Such restrictions are major impediments to FDI, and specifically Diaspora FDI. A large number of Indian entrepreneurs in the US, UK and other parts of the developed world are very successful retailers. Their expertise and capital are being prevented from being put to productive use in the Indian economy. A viable retail chain network often creates backward linkages with extremely positive effects on growth of efficient supply chain networks. Such networks in turn reduce cost to market and induce scale economies in several products that then become more competitive in the global market.

A walk into any furniture, stationary, hardware or electronics store in the industrialized world, especially the US, will show that most of the items that have been reserved for the SME sector (a few examples of which are presented in Table 6), are imported from developing countries, especially from China. The Chinese and other Asian exporters of such products into industrialized markets became competitive precisely because of economies of scale, low transaction costs and the ability to invest in quality control and productivity without restrictions. As long as the policy of reservation for the small-scale sector 
continues with its associated investment and scale of operation ceilings, Indian manufacturers will never be able to compete globally. As was pointed out, that does not mean just the loss of a potentially huge global opportunity; it will mean a gradual loss of the domestic market as well given that the forces of globalization will expose India to competition from China and other Asian countries.

Table 6: Common Consumer and Industrial Use Products Reserved for SME

\begin{tabular}{ll}
\hline 1 & Wooden furniture and fixtures \\
\hline 2 & Paper envelopes \\
4 & Teleprinter rolls \\
5 & Full PVC footwear (sandals and shoes) \\
6 & Polyethylene and PVC flexible hoses \\
7 & Graphite paints \\
8 & Industrial adhesives \\
9 & Formulated perfumery compounds \\
10 & Steel furniture and storage equipment \\
11 & Rolling shutters \\
12 & Stainless steel utensils \\
13 & Aluminum utensils \\
14 & Eoltage stabilizers \\
15 & Electric irons \\
16 & Espresso coffee makers \\
17 & Bread toasters \\
18 & Electrical light fitting chokes \\
19 & Electrical light fittings starters \\
20 & Ball point pens \\
\hline
\end{tabular}

Develop a Strategic Vision for FDI with focus on exports, technology, geographic specialization, and employment creation

In comparison with the Chinese approach, the Indian FDI regime suffers because it is passive (open to all, without any targeting) and not strategic as in China (Kao, 1993). India's FDI policy should have prioritized investment in labor intensive manufacturing, for acquisition of technology and for the establishment of international trading channels to facilitate labor-intensive exports. The FDI policy environment also lacks a sense of sectoral and geographic specialization. Certain regions of India, though backward on the whole, possess competitive natural and human resources in certain specific sectors. The FDI requirement and its international marketing network for that sector need to be identified and global leaders in that sector actively wooed with this geographic-sectoral specialization in mind. Businesses respond best to specific proposals with the guarantee of an enabling mechanism, generalized talk of potential and good intentions will not attract serious investors.

\section{Reduction in Transaction Costs, Improvement of Infrastructure and Enabling Trade Facilitation}

More than any FDI policy, it is the level of business comfort and profitability of operation that attract FDI. India had a more liberal trade regime than either China or Malaysia but was not even close to attracting the kind of FDI that these economies attract. Transaction costs of operating a business in India remain prohibitive and infrastructure and logistical support poor. India's export-import infrastructure including the soft infrastructure of information flows and administration of trade flows remain behind the standards set in other Asian economies such as Thailand, Malaysia and China. Transaction costs arising out of poor infrastructure, logistics and administration affect SME's and other smaller players the most. As it was pointed out, the average diaspora investor is most likely to be small scale and such investors will feel the persistence of high transaction costs most acutely. Under such conditions, very few diaspora investors are likely to invest. In order to attract FDI, India first must become a competitive production base where people would want to invest. Implementation of Trade Facilitation reforms will lead to stronger trade linkages with ASEAN and other emerging markets in Asia, an imperative if India is to become a global production hub (prospect of which will attract FDI). 


\section{Similar Treatment to International and Domestic Entrepreneurship}

Capital and associated entrepreneurship is an important factor of production. The quality of entrepreneurship is the key for productive efficiency in an economy. To give preferential treatment to FDI over domestic capital and the associated entrepreneurial resources that go with it is to restrict this factor of production from contributing efficiently in the economy. The success of the Indian entrepreneur is now recognized globally, especially by global financial institutions that are the best arbiters of global firm level efficiency. India should have a holistic investment policy that creates an enabling mechanism for both India's domestic as well as international investors and entrepreneurs, not single out preferential treatment for any one set of investors. Given India's deep savings pool and ability to generate investable capital (the large sums that was raised for Tata's takeover of Corus is a case to the point), this is of the essence.

\section{Decentralization of Administration Process}

A major reason behind China's relative success in attracting FDI has been the relatively higher level of decentralization of the FDI policy and administration process. According to Kundra (2000), the Indian FDI policy process still remains highly centralized in Delhi and that is a major impediment in effective competition between states and efficacy in administration of FDI initiatives in many parts of India. While things have improved in terms of decentralization since Kundra's analysis in 2000, the entire FDI policy environment still remains in centered around Delhi and not the state capitals where they should be given the diversity of India's economic geography.

\section{Drastically Reduce Overly Bureaucratic FDI facilities}

India's bureaucratic set-up maintains several investment and trade promotion bodies that work at cross purposes. There are too many 'single' windows and investment development commissions working at the same time. There is also a lack of policy consistency. For example, the Development India Initiative to showcase India as a manufacturing hub was discontinued without the initiative being allowed to reach a logical conclusion. There needs to be a real 'single window' that draws from the sectoral expertise of the different ministries, and more importantly the private sector. The Ministry of Overseas Indian Affairs can play this role for investment from the Indian diaspora and collaborate with the Department of Industrial Policy and Promotion, and the Foreign Investment Promotion Board that implement foreign investment policy.

\section{Private Public Partnership with Private Sector taking the lead}

Foreign investors are lured not by the proverbial persuasion of the bureaucracy or the politicians as they are by the broad policy framework, stability of the government and consistency in policy. Thus, having several government dominated investment commissions might not have any positive impact on FDI. Foreign investors are unlikely to be interested in holding talks with bureaucrats, ex-ministers or experts, however eminently qualified they might be. Foreign investors are more likely to respond to actual business plans and proposals from their business counterparts in India (Saxenian, 2000). Thus, the government should let the Indian private sector take the lead and provide the enabling mechanism. In this context, the formation of the Overseas Indian Facilitation Centre (OIFC) by the Government of India which is hosted by Confederation of Indian Industry (CII) is a step in the right direction. By letting CII be the host institution, the Government has effectively acknowledged that the private sector has to take the lead in this process. However, the OIFC has to become more than just a talk shop for it to play the role that has been assigned to it. More specifically the OIFC will have to nurtured and led by the top leadership in both the government and business because as Wei's analysis point out, agencies that have established reporting mechanisms to the highest country's policy makers (i.e., the president or prime minister) or to the private sector leadership (leading CEO's etc) have been systematically more efficient at attracting FDI.

\section{Networking Overseas Indian Professionals placed in key Decision making positions}

A large part of the FDI in the IT and ITES sector was facilitated by Indians placed in key decision making position in Silicon Valley based giant companies. The off shoring of business processes (BPO) also saw many Indian professionals and managers in major MNC's play an important role in mediating the movement of such investment into this industry in India. Thus, it is very important for FDI administrative 
bodies in general and the OIFC in particular to focus on these groups by maintaining a detailed sector specific database of such highly placed Indians and make them a part of the process of by inviting to OIFC deliberations. It is also important to tap diaspora human resource to make Indian enterprise more globally competitive. In firm level perspective this would involve engaging with diaspora managerial, technical and business talent worldwide to work for Indian enterprise. In a more macro-level perspective this would involve tapping diaspora human and financial capita for the development of India's domestic human resources and social sector. India's diaspora include several prominent names in the academic field. India is very likely to face an acute shortage of skilled human resources as the economy grows. The Indian higher education system is in a poor state (with some exceptions like the IIT's and IIM's) and there is a great need for investment in this sphere.

\section{Creative Joint Ventures (JV) and Partnership to tap Diaspora entrepreneurship}

Continuing on the theme of JV's, new and creative mechanisms need to be found to tap diaspora entrepreneurship for India. Joint Ventures and partnerships with Indian stakeholders provide the diaspora a firmer footing and surer way to deal with local risks. A few examples of the many ways by which diaspora entrepreneurship can invest and profit from the Indian market is given below:

\section{Marketing Joint Venture}

Establishing retail networks with the diaspora that source dedicatedly from Indian producers through a contractual agreement. Such an arrangement will work especially well in consumer goods, textiles and clothing. CII can contribute to the formation and the marketing through the Indian Brand Equity Fund (IBEF).

\section{Production Joint-Venture}

Actively encourage Indian corporate to strategically invest in venture capital funds that serve as a springboard for three way partnerships. The Indian corporate supported venture capital provides a part of the investment; another part is borne by an existing SME entrepreneur, while the third is borne by diaspora FDI. CII can have a dedicated investment wing that brings together the three groups. Such three way partnership can be used to augment existing production facilities, upgradation, or for new ventures.

\section{Diaspora-Small Entrepreneur Group Joint Ventures}

Identify successful small entrepreneurs operating in clusters, or in the same sector/production line in different geographies of India. Help consolidation and corporatization with the help of diaspora investment by selling the investment opportunity to interested diaspora members.

\section{Policies to Convert Remittances into Investment and Create Venture Capital}

India is the highest recipient of remittances in the world. India received just fewer than 25 billion USD worth of remittances in 2005, more than 3 times the amount of FDI for the same year ( 6.6 billion USD). Indians also invest heavily in India's bonds and funds market. The outstanding NRI deposits to be 32 billion USD in 2005. If such remittances and investable funds are properly harnessed, it can generate vast amounts of capital to finance India's industrial expansion just like FDI. Remittances can often play a significant role in providing working capital. Accumulation of capital from remittances might not necessarily show up as investment in enterprise defined by the formal sector, though such a phenomenon is not uncommon. The more substantive impact of remittances is likely to be felt through the easing of credit constraints in relatively poorer households that enable incremental investment in the more productive use of existing economic resources (Mahambare, 2001).

For example, remittances might allow credit constrained households to invest in better technology for agriculture or expand informal retail businesses. Return migrants can use their savings to invest in SME upon their return to their country of origin. Such entrepreneurial activity can be better organized if there was a policy environment that helped sustain it. Many countries such as Philippines and Mexico now actively help return migrants with investment advice and facilitation to enable productive investment of their savings from abroad. The investment of such savings is effectively a form of 'FDI'. In India's case, such remittance oriented FDI is pretty common in regions like Gujarat and Punjab where family networks 
draw capital from their members working abroad to finance their enterprise. Thus, the policy environment on FDI needs to take a broader view on the concept of foreign capital being invested in Indian enterprise and pay more attention to such SME activity being financed by diaspora networks. More importantly, diaspora networks could be organized into investment co-operatives that work with diaspora centric venture capital firms so small remittances can be channeled into bigger investment projects. The IT and ITES sector has seen the rise of Indian venture capital firms that work with the diaspora to channel their savings into Indian start-ups. It is time to create a policy environment and take initiatives to do the same for the manufacturing sector SME.

\section{Conclusion and Future Research}

Amidst today's time of fierce competition and a quest to achieve and enhance a substantial level of economic and social development; each and every nation is trying to liberalize its economic policies in order to attract investments from not only, domestic players, but also from magnates all across the globe. Consequently, people with generous reserves of funds, all around the globe, are expanding their wings and seeking opportunities for investing in different spheres of this lucrative market. India too is not oblivious to the rapid developments taking place in the global market and has emerged as one of the prime destinations for the investment of funds from an impressive number of foreign investors. FDI is a superb conduit for the transfer of technology and know-how to developing countries. This message has not been lost on India's policy makers. They have though until the decade of the nineties attempted to regulate and control its spheres of activity and the contractual forms of foreign enterprise participation in the economy. The framework of policies they put in place was guided by the desire to limit foreign control of economic activity but at the same time take advantage of the technology and know how provided by foreign capital. This attempt at riding two horses in tandem, a complex feat, inevitably resulted in a complex and cumbersome bureaucratically guided FDI regime and earned India the reputation for hostility towards FDI.

Even so, there are those who argue that a lot more needs to be done and India should throw all doors wide open to FDI. The spectacular growth of FDI in China is frequently invoked in support of this passionate advocacy of FDI. This paper has argued that this exuberance for FDI should be tempered by the recognition that FDI is a superb catalyst of growth and not an initiator, its efficacy in promoting development objectives is conditioned by the presence of co-operant factors in the host economies and it is most effective in countries which possess a threshold level of human capital. There is no reason to believe that inflows of large volumes of FDI alone necessarily promote the growth of the social product. The optimum level of FDI a country should aspire for is conditioned by the history and the stage of its industrialisation, the sources of FDI it has ease of access to and its endowments of co-operant factors and the sort of institutions it possess, facilitate and monitor the operations of foreign firms. For these reasons the thesis that India should regard China as a role model may be misconceived. The paper also suggests that India may now be better placed than in the past to effectively utilise licensing and technical collaboration agreements as opposed to FDI.

Apart from taking steps to improve infrastructural facilities and enhancing labor market flexibility, the highlights of ten further policy recommendations for India's FDI strategy is discussed for policymakers going forward and the future research should be done on these ten areas to brighten the Foreign Direct Investment towards India.

1. One, while the government has lifted sectoral caps for FDI over the last decade, policies have thus far been piecemeal and ad-hoc and a source of uncertainty. Particular attention should also be paid to the removal of restrictions on FDI in the services sectors -- including telecoms, banking and insurance, aviation, etc - as this will help easy transactions costs for both consumers and business.

2. Two, as a means of trying to overcome some of the hindrances to large-scale investments in the manufacturing sector. It is often noted that such a strategy was successfully undertaken by China and used effectively by the government in policy experimentation before being replicated on a larger scale.

3. Three, focus should not just be on the absolute amount of gross FDI inflows but also the type. More specifically, while India has experienced an infusion of FDI inflows in recent times, a large portion of the new inflows have been in the form of M\&As. 
4. Four, over and above the creation of a business-friendly environment, it may be important for a potential host country to actively undertake investment-promotion policies to fill in information gaps or correct perception gaps that may hinder FDI inflows.

5. Five, while India must do image-building exercises to promote it as a favourable investment location; it desperately needs to get rid of the tag that it can only do services and not manufacturing. Between India and China, ask any businessman about where they will invest their money: if it is service sector related, the answer, more often than not, is India and when it is manufacturing sector related, the answer is mostly always China.

6. Six, is the desperate need to create a deep talent pool. Again an activity that is easier said than done because it takes time to create a deep talent pool. If one looks at investment bank reports on India, one point that gets constantly highlighted is the lack of talent at all levels. This is inherently dangerous for a country like India which has a tag of a services country; a sector that needs a deep talent pool to feed off. This lack of talent is reflected in the growth in wages which is one of the highest in the world.

7. Seven, the Government continues to advocate a policy of targeted promotion, suggesting it has potentially high payoffs, though also acknowledging that it can be a risky proposition. It finds support from the successes of countries like Singapore whose investment promotion authority, the Economic Development Board (EDB), has quite successfully targeted specific global corporations to meet their specific locational requirements, or broad sectors to invest in the city state.

8. Eight, while many policy barriers have been removed on FDI in India, results have at times been disappointing due to administrative barriers at the state level as well as lack of coordination between the central and state governments. There need to be greater coordination between the centre and states to ensure that the substantial foreign interest in investing in India gets translated into actual investment flows to the state.

9. Nine, India should continue to work towards developing a deep and liquid corporate debt market. India is one of the few countries with a major equity market but with a highly illiquid corporate debt market. A well functioning corporate debt market does one major thing for companies looking to invest in India. It is very likely that when companies are investing their money in India or in any other country, they are more likely to use debt rather than their own cash. Therefore, they would go to debt markets in their countries of origin and raise money there.

10. Ten, India should consciously work towards attracting greater FDI into R\&D as a means of strengthening the country's technological prowess and competitiveness. If India is to do so, there needs to be a strengthening in intellectual property rights or IPRs.

So,

Invest in India....

Let the FDI inflows into India...

Let India lead the global market...

\section{References}

Agarwal, J. (1980). Determinants of Foreign Direct Investment: A Survey, Weltwirtschaftliches Archive, 116: 739-773.

Aggarwal, A. (2000). Liberalization, MNE Affiliates and Export Performance. Indian Manufacturing, Institute of Economic Growth Discussion Papers, no 19, Delhi.

Balasubramanyam, V. N. and Salisu, M. (1991). Export Promotion, Import Substitution and Direct Foreign Investment in Less Developed Countries" in Koekkoek, A. and Mennes, L. (eds.), International Trade and Global Development (London: Routledge).

Balasubramanyam, V. N., Salisu, M. and Sapsford, D. (1999). Foreign Direct Investment as an Engine of Growth. Journal of International Trade and Economic Development, 8: 27-40.

Buckley, P. J., and Casson, M. (1991). The Future of the Multinational Enterprise. (London: Macmillan).

Dunning, J. H. (1973). The Determinants of International Production. Oxford Economic Papers, 25: 289336.

Dunning, J. H. (1993). Multinational Enterprises and the Global Economy. (Workingham: Addison-Wesley). Government of India (GOI), (2010). Foreign Direct Investment Policy, Ministry of Commerce and Industry, Department of Industrial Policy and Promotion.

Hymer, S., H. (1976). The International Operations of National Firms: A Study of Direct Foreign Investment", MIT Press, Cambridge, Mass. 
Kao, J. (1993).The Worldwide Web of Chinese Business. Harvard Business Review, 2: 24-26.

Kathuria, V. (2000). Productivity Spillovers from Technology Transfer to Indian Manufacturing Firms. Journal of International Development, 12: 343-369.

Kearney, A. T. (2010), FDI Confidence Index 2010 report.

Kundra, A. (2000). The Performance of India's Export Zones: A Comparison with the Chinese Approach. Sage Publications.

Levis, M. (1979). Does Political Instability in Developing Countries Affect Foreign Investment Flows? An Empirical Examination. Management International Review. 19: 59-68.

Mahambare, V. (2001). Economic Reforms in India: Impact on Savings and Productivity of the Manufacturing Sector (PhD Dissertation, International Business Group, Department of Economics, Lancaster University) RBI's Bulletin January $2011 \mathrm{dt}$. January 12, .2011.

Root, F. and Ahmed, A. (1979). Empirical Determinants of Manufacturing Direct Foreign Investment in Developing Countries, Economic Development and Cultural Change, 27: 751-68

Saxenian, A. L. (2000). Back to India, Wall Street Journal (Supplement: Technology Journal Asia).

Wei, W. (2005). China and India: Any Differences in Their FDI Performance. Journal of Asian Economies, 16: 719-736.

World Bank (2007). Doing Business 2008, Washington, DC: World Bank. 